\title{
Migration Fuels a Second Year of Higher Population Gain in New Hampshire
}

Kenneth M. Johnson

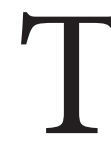

The population of New Hampshire grew by 6,700 between July of 2017 and July of 2018 to 1,356,000 according to new Census Bureau estimates. This gain coupled with a population increase of 7,400 last year added 14,100 residents to the state between 2016 and 2018. This gain is 50 percent greater than the increase between 2014 and 2016, though it remains modest compared to gains in the 1970s and 1980s. Migration accounted for nearly all of this growth. The state had a net domestic migration gain of nearly 8,700 residents from other states between 2016 and 2018. This is a striking change from a migration increase of just 600 between 2014 and 2016, as well as from earlier in the decade when more people left New Hampshire for other U.S. destinations than moved to the state. New Hampshire also received 5,200 immigrants from other nations between 2016 and 2018, somewhat fewer than in the past. Births in New Hampshire now only minimally exceed deaths and thus contributed little to the population gain. The natural change was less than 400 between 2016 and 2018 because the 24,400 births in the period were largely offset by 24,000 deaths. Over the last decade, births have diminished because fertility rates are low and the child-bearing age population has not grown. In contrast, deaths increased because of population aging and more drug-related deaths. Population gains are occurring both in metropolitan and rural areas of the state. This analysis uses Census Bureau estimates that have been reasonably accurate in the past but should be interpreted with caution.

\section{AS NEW HAMPSHIRE GAINS MORE MIGRANTS FROM OTHER STATES, ITS POPULATION GROWTH ACCELERATED IN THE PAST TWO YEARS}

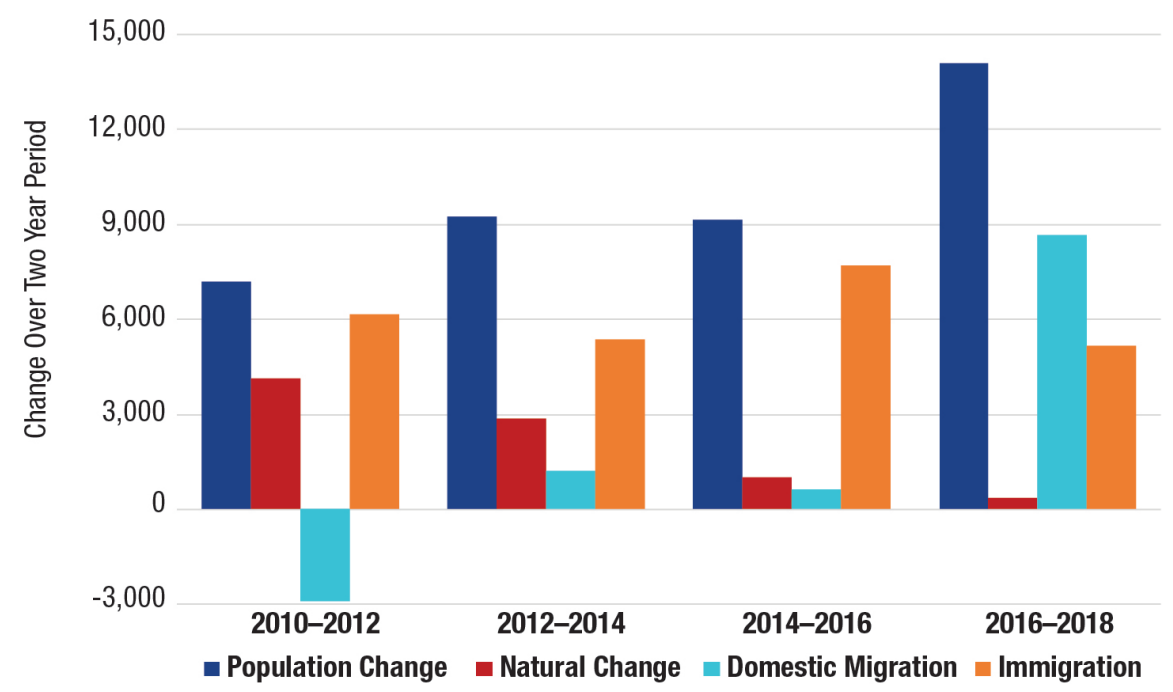

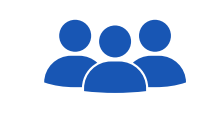

Migrants from other states fueled a second year of greater population increase in New Hampshire.

See related publication at carsey.unh.edu

- Migration Fuels Largest New Hampshire Population Gain in a Decade (December 2017)

Source: Census Bureau Estimates, 2019

Huddleston Hall • 73 Main Street • Durham, NH 03824 carsey.unh.edu $\bullet 603.862 .2821$
TTY USERS: DIAL 7-1-1 OR

1-800-735-2964 (RELAY N.H.) 